\title{
Diversidade genética e estrutura populacional dos crocodilianos jacaré-açú (Melanosuchus niger) e jacaré-tinga (Caiman crocodilus) da Amazônia
}

\author{
William Rangel Vasconcelos
}

\begin{abstract}
Resumo
Os crocodilianos Amazônicos são incluídos em três gêneros, Caiman, Melanosuchus e Paleosuchus. Dentro destes, duas espécies merecem atenção especial porque foram muito exploradas em décadas passadas e hoje passam por uma recuperação populacional, o jacaré-tinga (Caiman crocodilus) e o jacaré-açú (Melanosuchus niger), que são os crocodilianos mais abundantes da Amazônia brasileira. Esta pesquisa foi realizada com o objetivo de quantificar o grau de variabilidade genética e estrutura populacional dos crocodilianos $M$. niger e $C$. crocodilus, através de um marcador de linhagem materna (gene mitocondrial citocromo $b$ ), e desta forma, contribuir com informações que possam ser utilizadas em futuros planejamentos para a conservação e o manejo destas espécies. Com base nas análises de aproximadamente 1.080 pares de bases obtidas para um total de 125 indivíduos de $C$. crocodilus e 132 de $M$. niger provenientes de 9 e 11 localidades respectivamente, em diferentes regiões da Amazônia Brasileira, Peru, Equador e Guiana Francesa, foi possível identificar padrões genéticos biogeográficos. Os resultados demonstram que algumas populações de ambas as espécies estão em expansão populacional mostrando um número relativamente grande de haplótipos únicos. Ambas as espécies apresentaram elevada diversidade gênica e baixa diversidade nucleotídica. As análises de clados agrupados indicaram expansão, colonização a longa distância e fragmentação no passado, como possíveis eventos histórico-demográficos em populações de $C$. crocodilus. Em M. niger, os dados não foram conclusivos para identificar possíveis eventos históricos. Entretanto, possibilitaram identificar a existência de correlação entre divergência genética e distância geográfica. Esta correlação também foi identificada pelo teste de Mantel, indicando isolamento por distância em $M$. niger e pelos valores significativos de pairwise $F_{\text {st }}$ que confirmaram a ocorrência de fragmentação. Esta fragmentação foi identificada entre as populações oriundas de rios que deságua diretamente nas drenagens do oceano Atlântico em relação às populações da bacia Amazônica, entretanto, dentro da bacia Amazônica algumas populações também apresentaram estrutura genética populacional, como por exemplo, a população de $M$. niger do rio Napo. As populações da Guiana Francesa e do Estado do Amapá representam
\end{abstract}

potenciais unidades evolutivas diferenciadas das populações da bacia Amazônica.

Palavras-chave: variabilidade genética, crocodilianos, Melanosuchus niger, Caiman crocodilus, DNAmt, citocromo $b$, fragmentação populacional.

\section{FICHA CATALOGRÁFICA}

BIBLIOTECA DO INSTITUTO NACIONAL DE PESQUISAS DA AMAZÔNIA

Vasconcelos, William Rangel

Diversidade genética e estrutura populacional dos crocodilianos jacaré-açú (Melanosuchus niger) e jacaré-tinga (Caiman crocodilus) da Amazônia. -2005.

xviii, 78 f. : il.

Dissertação (mestrado)-INPA/UFAM, 2005.

1. Amazônia 2. Melanosuchus niger 3. Caiman crocodilus 4. Filogeografia 5. Citocromo $b \quad 6$. Freqüência haplotípica 7. Genética da conservação.

CDD 19. ed. 597.980415 